\title{
Characteristics of women applying for a legal abortion in the Islamic Republic of Iran
}

Seyedeh Fatemeh Vasegh Rahimparvar ${ }^{1}$, Asieh Jafari ${ }^{2}$, Fatemeh Hoseinzadeh ${ }^{3}$, Faezeh Daemi ${ }^{4}$ and Fatemeh Samadi ${ }^{2}$

${ }^{1}$ Nursing and Midwifery Care Research Centre, Midwifery Department, Nursing and Midwifery School, Tehran University of Medical Sciences, Tehran, Islamic Republic of Iran (Correspondence to: S. Fatemeh Vasegh Rahimparvar: vaseghrh@tums.ac.ir). ${ }^{2}$ Iran Legal Medicine Organization Research Centre, Tehran, Islamic Republic of Iran. ${ }^{3}$ School of Medicine, Gilan University of Medical Sciences, Rasht, Islamic Republic of Iran. ${ }^{4}$ School of Fine Arts, University of Tehran, Tehran, Islamic Republic of Iran.

\begin{abstract}
Background: Legal abortion has been permitted in the Islamic Republic of Iran since 2003 if there is serious and incurable disease that would cause the mother or the fetus suffering.

Aims: This study evaluated the characteristics of women applying for a legal abortion licence to the Tehran Province General Office of Legal Medicine, and compared the findings with earlier studies to evaluate changes over time.

Methods: All women visiting the office between August 2011 and 2012 to apply for a legal abortion licence were interviewed and sociodemographic data, reason for the application and outcome of the application were recorded.

Results: A total of 1378 women applied for a licence, and $48 \%$ were issued. Most applications (80.6\%) were for fetal rather than maternal indications and $90.2 \%$ of the licences issued were for fetal indications. Most of the applications for fetal indications (53.7\%) were granted a licence, while $75.7 \%$ for maternal indications were rejected. Neurological abnormalities in the fetus were the most common reason for the application (24.6\%) and licences issued (30.7\%). Neurological and psychological disorders were the most common maternal reason in all applications $(25.7 \%)$ and in unsuccessful applications $(28.6 \%)$. Cardiac disease (23.1\%) was the most common maternal reason in successful applications.
\end{abstract}

Conclusions: Comparison of the results with those of earlier studies shows an increase in the number of women applying for a legal abortion licence and in the number of licences issued. Similar studies are recommended to provide information on the effect of national abortion laws and help improve the legal abortion process in the Islamic Republic of Iran.

Keywords: Pregnancy; abortion, legal; abortion licence; Iran

Citation: Vasegh Rahimparvar SF; Jafari A; Hoseinzadeh F; Daemi F; Samadi F. Characteristics of women applying for a legal abortion in the Islamic Republic of Iran. East Mediterr Health J. 2018;24(11):1040-1048. https://doi.org/10.26719/emhj.18.001

Received: 11/12/15; accepted: 16/11/17

Copyright (c) World Health Organization (WHO) 2018. Some rights reserved. This work is available under the CC BY-NC-SA 3.o IGO license (https:// creativecommons.org/licenses/by-nc-sa/3.o/igo).

\section{Introduction}

Abortion refers to the termination of pregnancy before the 2oth week of gestation or a fetus less than $500 \mathrm{~g}$ of weight, and may be spontaneous or induced (medically, non-medically or criminally) (1). Therapeutic or legal abortions are performed for medical reasons related to the mother or the fetus (2). In some countries there are legal restrictions on abortion (3). Given its integration with legal, judicial, moral and social issues, abortion is not just a medical problem (4). Before the 1979 Islamic Revolution in Iran, abortion was legal for the purposes of saving a mother's life or her mental and physical health, or after diagnosis of fetal defects. After the revolution, however, abortion regulations were abolished, and abortion was allowed only in the few cases in which the pregnancy threatened the life of the mother $(5,6)$.

The legal vacuum on legal abortions was problematic in the Islamic Republic of Iran because many fetal anomalies and diseases existed. This became a subject of discussion in 1997 following a fatwa by the Supreme Leader of the Islamic Revolution authorizing legal abortion for fetuses with major thalassemia. Based on Islamic law and guided by modern medicine, the medical abortion law was prepared in 2003, revised and ratified by the Islamic Parliament in $2005(6,7)$, and approved by the Guardian Council on 15 June 2005. The law states that:

legal abortion is allowed provided that three specialists make definite diagnoses about the fetus being malformed or retarded, thus causing the mother to suffer severely, or about the mother's own life-threatening conditions, and given the general office of legal medicine's final approval, provided the fetus is not yet four months old, the time at which spirit is breathed into it, and provided the mother's consent, and the superintendent doctor has no responsibilities toward the matter and will not be punishable by law with regard to this action.

Based on this law, the Iranian Legal Medicine Organization has adopted procedures in recent years for authorizing legal abortion, which require at least one of a list of 51 conditions to be met for a licence to be issued; 22 relate to the health of the mother and 29 to the health of the fetus. These 51 conditions are serious and incurable diseases that will cause the mother, the fetus or the future child to suffer $(6,8,9)$. The Supreme Leader of Iran, Ayatollah Khamenei, issued a fatwa on this matter in 2003, stating that, "if the fetal condition can be definitively 
diagnosed, and if the survival of this fetus causes serious suffering, which is typically the case, performing an abortion is permitted before the spirit is breathed into the fetus. However, to take precaution, the blood money (dieh) for the fetus should be paid" $(6,8)$. To summarize, the therapeutic abortion law was approved by the Iranian parliament in 2003. Before this law, abortion permissions were severely restricted in the Islamic Republic of Iran. At that time, a guideline on indications for abortion was presented by the Legal Medicine Organization of Iran. Parliament and the Islamic Consultative Assembly approved this in 2005 (2).

Epidemiological studies are important to determine the current status of a condition and estimate the facilities needed to manage it (10). Given the undeniable problems and complications caused by induced abortion, understanding the different aspects of the issue and devising appropriate strategies to eliminate or reduce these problems is essential (11).

With the ratification of the abortion law in 2003, various studies have been conducted on abortion in general in Iran and the effect of the abortion laws $(7,12)$. Sadr and colleagues conducted a study to examine abortion licences issued by the Iranian Legal Medicine Organization from 22 December 2003 to 20 December 2004. They found that a substantial number of individuals who would have previously have sought an illegal abortion began to apply for a legal abortion after the law was passed, and concluded that this change had a significant positive effect on the health of mothers (7). Another study on abortion licences issued by Kerman Province General Office of Legal Medicine in 2005 compared the results with those obtained in previous years and concluded that the increase in the number of legal abortion licences issued had reduced the number of illegal abortions, which had in turn improved the health and safety of pregnant women (12).

These studies have undoubtedly contributed to the decisions made by the authorities for new abortion acts. Studying the characteristics of women applying for legal abortion licences, the reasons for their application and the result of the application would be useful to the authorities to help them better evaluate the current status of abortion and compare them with previous or future years and take appropriate action to address any limitations. Therefore, the aim of our study was to evaluate applications for a legal abortion licence made through the Tehran Province General Office of Legal Medicine in 2011-2012. Our specific objectives were to assess the characteristics (socioeconomic and obstetric) of the women applying for legal abortion, the reasons for applying for an abortion and the result of the application (issuance or non-issuance of the abortion licence).

\section{Methods}

\section{Study design and sample}

This was a prospective study of all the women who visited the Tehran Province General Office of Legal Medicine to apply for a legal abortion licence between 23 August 2011 (1/6/1390 Iranian calendar) and 21 August 2012 (31/5/1391 Iranian calendar).

\section{Data collection}

In Tehran Province General Office of Legal Medicine, women applying for a legal abortion are referred to the Women's Office. The outcome of the application is usually received after one or two visits and on the same day in the case of fetal indications for a legal abortion licence. For applications based on indications of the mother, the outcome takes three days to one week.

For data collection, the women were approached on their last visit when the outcome of their application for a legal abortion licence was confirmed. Most of the women agreed to be interviewed and for their data to be reviewed; 11 women did not wish to be interviewed but some information was available for them, namely: reason for applying for an abortion licence, fetal or maternal indication for the abortion, fetal age, issuance of the abortion licence or not, if not, the reason for not issuing the licence. The data were collected by two of the researchers of this study (AJ and FS) who worked at the Women's Office.

The researchers interviewed the women at the Women's Office and data were also obtained from the women's medical documents. The data recorded for each women included: age, husband's age, level of education, occupation, husband's occupation, gravidity, parity, number of living children, history of abortion, number of abortions, reason for requesting an abortion, type of fetal or maternal indication for the abortion, history of using medications for every acute/chronic disease or exposure to radiation during pregnancy, fetal age, person or place referring the woman, issuance of the abortion licence or not, if not, the reason for not issuing the licence, and reason for any delays in applying for the licence.

\section{Statistical analysis}

The data obtained were analysed using descriptive statistics. Participants were divided into 2 groups - those who were issued the licence and those who were not. Differences between the 2 groups were compared according to socioeconomic and obstetric characteristics using the independent t-test (for continuous variables) and the chisquared test (for categorical variables).

Mother's medication use, her diagnosis of communicable diseases that could cause fetal anomalies and her exposure to radiation were considered fetal indications for an abortion in the analysis of the data as they could have adverse effects on the fetus. Some fetal problems that did not require an abortion licence or that should have been followed up by a hospital were also taken to be fetal indications, including partial moles, intrauterine growth restriction, abnormal amniotic fluid, intrauterine fetal death and a blighted ovum.

\section{Ethical considerations}

The study was approved by the Ethics Committee of Teh- 
ran University of Medical Sciences.

A letter of introduction was provided by the authorities of Tehran University of Medical Sciences to the Tehran Province General Office of Legal Medicine. The researchers explained the objectives of the study to the office authorities and obtained their consent before collecting data on the women.

The researchers explained the objectives of the study to the women visiting the office to apply for a legal abortion licence and recorded their data. The women were assured that the information they gave would be kept confidential and they gave their verbal, informed consent to participate.

\section{Results}

Over the study period (23 August 2011 to 21 August 2012), 1378 women visited the Tehran Province General Office of Legal Medicine to apply for a legal abortion licence; of these, 661 women (48\%) were issued the licence and 717 women (52\%) were not. Tables 1 and 2 show the socioeconomic and obstetrics characteristics of the women categorized according to their licence status (issued or not). The majority of the women in both groups had a high school diploma and above, were housewives, had a history of abortion, used medication or were exposed to radiation during the pregnancy, had similar problems in the family, and were referred by a gynaecologist. There were significant differences between the 2 groups for the women's age, husband's age, number of living children, number of sons and daughters, medication use or exposure to radiation during pregnancy, referral person/place, gestational age based on ultrasound, gravidity, parity, number of spontaneous abortions, and gestational age based on abdominal examination (Tables 1 and 2).

A total of 1110 women (80.6\%) had applied for an abortion licence for fetal indications, while 268 women (19.4\%) had requested it for maternal indications. In the group issued a licence, 596 women (90.2\%) had requested an abortion licence for fetal indications while 65 (9.8\%) had requested it for maternal indications. In the group not issued a licence, 514 women $(71.7 \%)$ had requested an abortion licence for fetal indications and 203 women (28.3\%) for maternal indications. Just over half (53.7\%) of the women applying for a licence for fetal indications were granted the licence, while only $24.3 \%$ requesting a licence for maternal indications were given a licence.

The greatest proportion of the women applying for an abortion licence for fetal indications had a fetus with neurological abnormalities (26.0\%); neurological abnormalities were the most frequent reason for applying for an abortion licence in both the group that was issued a licence (33.9\%) and the group that was not (16.9\%). Eye anomalies, mother's medication use, mother's diagnosis of communicable diseases that could cause fetal anomalies, mother's exposure to radiation, positive screening test results for fetal anomalies without confirmation (i.e. without ultrasound or amniocentesis), partial moles, intrauterine growth restriction, abnormal amniotic fluid, intrauterine fetal death and a blighted ovum were conditions/factors for which an abortion licence was never issued (Table 3).

Neurological and psychological disorders were the most frequent reasons for applying for an abortion licence because of maternal indications (25.7\%). In the group issued a licence, the most frequent reason for requesting an abortion was cardiac disease (23.1\%), while in the group that was not issued a licence, neurological/ psychological disorders $(28.6 \%)$ was the most common reason. No abortion licences were issued for women with lung disease, thyroid disorders, unwanted pregnancy, old age, abnormalities in their other children and paternal problems, such as abnormalities or medical disorders (Table 4).

The most frequent reasons for non-issuance of an abortion licence were gestational age over 19 weeks (23.4\%), fetal anomalies not confirmed (16.9\%) and the absence of life-threatening risks for the mother (16.6\%). The most frequent reasons for the 19-week delay in visiting the office included failure to undergo ultrasound imaging before the gestational age of 19 weeks (36.2\%) and failure to have the anomaly diagnosed by the ultrasound images obtained before this date (27.5\%).

\section{Discussion}

During the year surveyed (23 August 2011 to 22 August 2012) in our study, 1378 women visited the Tehran Province General Office of Legal Medicine to apply for a legal abortion licence, and almost half (48\%) were issued a licence. A previous study of 245 women applying for a legal abortion licence at this office, from May 1999 to May 2000, reported that 126 (51.4\%) of the women were issued a legal abortion licence, while 119 (48.6\%) were not, because of a lack of sufficient indications (13). The percentage of licences issued in this earlier study is similar to ours. However, the number of women applying for a licence was different; far more women applied for an abortion licence in our study indicating a 5.6 times increase in abortion licence applications in 2011-2012 compared with 1999-2000. In the General Office of Legal Medicine in Kerman Province in 2005, 24 out of the 47 women applying for a licence in that year were issued one (12), which is also consistent with our results, suggesting that almost half of the women have been successful in their application for a licence.

Our study also showed that more women requested an abortion licence for fetal rather than maternal indications $(80.6 \%$ versus $19.4 \%$ ), and similarly more licences were issued (90.2\% versus 9.8\%) for fetal than maternal indications. Moreover, most of the applications for a licence for fetal indications were granted a licence (53.7\%), while most applications for maternal indications were rejected (75.7\%). Our findings differ from other studies. A study conducted on legal abortion licences issued by the Iranian Legal Medicine Organization in 2004 showed that the reasons for issuing a licence to 1 101 women included fetal anomalies and diseases in $64 \%$ of the cases and maternal conditions in $36 \%$ (7). In the study in 2005 in Kerman, $68 \%$ of the licences issued 


\begin{tabular}{|c|c|c|c|c|c|}
\hline \multirow{2}{*}{ Socioeconomic characteristic } & \multicolumn{2}{|c|}{ Licence issued ( $n=661$ ) } & \multicolumn{2}{|c|}{ Licence not issued $(n=717)$} & \multirow[t]{2}{*}{ P-value } \\
\hline & No. & $\%$ & No. & $\%$ & \\
\hline \multicolumn{6}{|l|}{ Level of education } \\
\hline Illiterate & 19 & 2.9 & 26 & 4.0 & $0.203^{\mathrm{a}}$ \\
\hline Elementary school & 65 & 10.1 & 80 & 12.4 & \\
\hline Middle school & 78 & 12.1 & 78 & 12.1 & \\
\hline High school & 25 & 3.9 & 39 & 6.0 & \\
\hline Diploma & 270 & 41.8 & 255 & 39.4 & \\
\hline University degree & 189 & 29.3 & 169 & 26.1 & \\
\hline Total & 646 & 100 & 647 & 100 & \\
\hline \multicolumn{6}{|l|}{ Occupation } \\
\hline Housewife & 556 & 85.7 & 561 & 85.0 & $0.886^{a}$ \\
\hline Employed & 70 & 10.8 & 76 & 11.5 & \\
\hline Labourer & 1 & 0.2 & 2 & 0.3 & \\
\hline Self-employed & 11 & 1.7 & 13 & 2.0 & \\
\hline Other & 11 & 1.7 & 8 & 1.2 & \\
\hline Total & 649 & 100 & 660 & 100 & \\
\hline \multicolumn{6}{|l|}{ Husband's occupation } \\
\hline Employed & 207 & 32.1 & 206 & 31.5 & $0.988^{\mathrm{a}}$ \\
\hline Labourer & 147 & 22.8 & 147 & 22.5 & \\
\hline Self-employed & 269 & 41.7 & 276 & 42.3 & \\
\hline Other & 22 & 3.4 & 24 & 3.7 & \\
\hline \multirow[t]{2}{*}{ Total } & 645 & 100 & 653 & 100 & \\
\hline & \multicolumn{2}{|c|}{ Mean (SD) } & \multicolumn{2}{|c|}{ Mean (SD) } & \\
\hline Age (years) & \multicolumn{2}{|c|}{$29.5(6.45)$} & \multicolumn{2}{|c|}{$30.7(6.56)$} & $0.001^{b}$ \\
\hline Husband's age (years) & \multicolumn{2}{|c|}{$33.3(6.58)$} & \multicolumn{2}{|c|}{$35.0(7.45)$} & $<0.001^{\mathrm{b}}$ \\
\hline No. of living children & \multicolumn{2}{|c|}{$0.8(0.91)$} & \multicolumn{2}{|c|}{$1.1(1.00)$} & $<0.001^{\mathrm{b}}$ \\
\hline No. of sons & \multicolumn{2}{|c|}{$0.5(0.62)$} & \multicolumn{2}{|c|}{$0.6(0.69)$} & $0.020^{b}$ \\
\hline No. of daughters & \multicolumn{2}{|c|}{$0.5(0.76)$} & \multicolumn{2}{|c|}{$0.7(0.76)$} & $0.005^{b}$ \\
\hline
\end{tabular}

${ }^{a}$ Chi-squared test; ${ }^{b}$ Independent t-test.

$S D=$ standard deviation

were because of fetal indications (12) and in the previous study at the Tehran office in 1999-2000, 17\% were issued because of fetal indications (13).

The time differences in the studies may be responsible for this difference; in 1999-2000, the legal abortion law had not yet been ratified, which would explain why only $17 \%$ of abortion licences were issued for fetal indications. However, in 2003-2004, i.e. a year after the ratification of the law, the number of licences issued for fetal indications increased to $64 \%$ and then to $68 \% 2$ years after execution of the law. It is therefore only natural for the number of women applying to the Office of Legal Medicine for an abortion licence for fetal indications to have increased 9 years after the law took effect. In fact, increased awareness in mothers and medical personnel about this law and the more frequent referral of mothers to legal medicine offices have played a key role in this increase.

In our study, fetal neurological abnormalities were the most frequent reason for requesting an abortion licence in cases with fetal indications (24.6\%). Applications on this basis also had the highest rate of success in having the licence issued (30.7\%).

The greatest proportion of the women in our study who applied for an abortion licence because of maternal indications did so because of neurological and psychological conditions $(25.7 \%)$. For those issued a licence, the reasons included cardiac disease (23.1\%), cancer $(18.5 \%)$, and neurological and psychological diseases (16.9\%). In the group not issued a licence, $28.6 \%$ were for neurological and psychological diseases. No abortion licences were issued for applications because of lung disease, thyroid disorder, unwanted pregnancy, old age, abnormalities in the other children and paternal problems. The previous study at the Tehran Office of Legal Medicine in 1999-2000 reported cardiovascular diseases in the mother $(27 \%)$, fetal problems $(17 \%)$ and renal disease in the mother $(11 \%)$ as the most frequent reasons for visiting the office, and cardiovascular diseases in the 


\begin{tabular}{|c|c|c|c|c|c|}
\hline \multirow[t]{2}{*}{ Obstetric characteristic } & \multicolumn{2}{|c|}{ Licence issued $(n=661)$} & \multicolumn{2}{|c|}{ Licence not issued $(n=717)$} & \multirow[t]{2}{*}{ P-value } \\
\hline & No & $\%$ & No. & $\%$ & \\
\hline \multicolumn{6}{|l|}{ History of abortion } \\
\hline Yes & 470 & 73.7 & 514 & 78.1 & $0.172^{\mathrm{a}}$ \\
\hline No & 167 & 26.2 & 143 & 21.7 & \\
\hline Total & 638 & 100 & 658 & 100 & \\
\hline \multicolumn{6}{|l|}{$\begin{array}{l}\text { Medication regimen or exposure to } \\
\text { radiation during pregnancy }\end{array}$} \\
\hline Yes & 556 & 86.7 & 419 & 63.5 & $<0.001^{a}$ \\
\hline No & 85 & 13.3 & 241 & 36.5 & \\
\hline Total & 641 & 100 & 660 & 100 & \\
\hline \multicolumn{6}{|l|}{ Similar problems in the family } \\
\hline Yes & 521 & 90.6 & 422 & 87.7 & $0.80^{a}$ \\
\hline No & 54 & 9.4 & 59 & 12.3 & \\
\hline Total & 575 & 100 & 481 & 100 & \\
\hline \multicolumn{6}{|l|}{ Referred by: } \\
\hline Gynaecologist & 479 & 75.8 & 468 & 73.2 & $<0.001^{\mathrm{a}}$ \\
\hline Midwife & 33 & 5.2 & 29 & 4.5 & \\
\hline Medical centre & 10 & 1.6 & 5 & 0.8 & \\
\hline General physician & 1 & 0.2 & 9 & 1.4 & \\
\hline Radiologist & 4 & 0.6 & 5 & 0.8 & \\
\hline Other specialists & 105 & 16.7 & 123 & 19.3 & \\
\hline \multirow[t]{2}{*}{ Total } & 632 & 100 & 639 & 100 & \\
\hline & \multicolumn{2}{|c|}{ Mean (SD) } & \multicolumn{2}{|c|}{ Mean (SD) } & \\
\hline GA based on ultrasound (weeks) & \multicolumn{2}{|c|}{$15.4(3.16)$} & \multicolumn{2}{|c|}{$14.7(7.72)$} & $0.027^{b}$ \\
\hline Gravidity & \multicolumn{2}{|c|}{$1.9(1.34)$} & \multicolumn{2}{|c|}{$1.2(1.46)$} & $0.006^{\mathrm{b}}$ \\
\hline Parity & \multicolumn{2}{|c|}{$0.8(0.93)$} & \multicolumn{2}{|c|}{$1.1(1.05)$} & $0.001^{\mathrm{b}}$ \\
\hline Number of abortions & \multicolumn{2}{|c|}{$0.4(0.74)$} & \multicolumn{2}{|c|}{$0.4(0.78)$} & $0.244^{b}$ \\
\hline Number of spontaneous abortions & \multicolumn{2}{|c|}{$1.2(0.63)$} & \multicolumn{2}{|c|}{$1.5(1.07)$} & $0.019^{\mathrm{b}}$ \\
\hline Number of legal abortions & \multicolumn{2}{|c|}{$1.0(0.40)$} & \multicolumn{2}{|c|}{$0.9(0.24)$} & $0.165^{\mathrm{b}}$ \\
\hline Number of illegal abortions & \multicolumn{2}{|c|}{$0.7(0.50)$} & \multicolumn{2}{|c|}{$1.0(0.43)$} & $0.345^{b}$ \\
\hline $\begin{array}{l}\text { GA based on abdominal } \\
\text { examination (weeks) }\end{array}$ & \multicolumn{2}{|c|}{$15.9(3.02)$} & \multicolumn{2}{|c|}{$18.9(4.83)$} & $<0.001^{\mathrm{b}}$ \\
\hline
\end{tabular}

${ }^{a}$ Chi-squared test; ${ }^{b}$ Independent t-test.

$S D=$ standard deviation, $G A=$ gestational age

mother (36\%), major thalassaemia in the fetus $(17 \%)$ and malignancies in the mother $(17 \%)$ as the most frequent indications among women who were granted a licence (13). The 2003-2004 study found the most common fetal indications for issuance of an abortion licence were anencephaly and major thalassaemia, and the most common maternal indication was cardiovascular diseases (7). The 2005 study in Kerman also reported major beta thalassaemia as the most common fetal indication and cardiovascular diseases as the most common maternal indication for applying for an abortion licence (12).

These studies are consistent with our study in terms of the maternal indications reported for issuance of legal abortion licences-cardiovascular diseases. However, their findings about fetal indications differ from our findings. In 1999-2000, the only fetal indication was major thalassaemia; in 2003-2004, anencephaly and major thalassaemia were the most common fetal indications; and in 2005, major thalassaemia was the most common fetal indication. In our study, fetal neurological abnormalities was the most frequent reason for the issuance of an abortion licence for fetal indications.

The preparation of the legal abortion law by the Iranian Legal Medicine Organization in 2003 and its ratification by the Islamic Parliament in 2005 appear to have greatly increased the issuance of legal abortion licences for fetal indications, as applications with a variety of fetal indications were granted the licence after 2005 . Therefore, based on the results of our study, it appears only reasonable that fetal neurological abnormalities and genetic disorders would be the most frequent fetal indications for an abortion licence being issued. 


\begin{tabular}{|c|c|c|c|c|c|c|c|}
\hline \multirow{2}{*}{$\begin{array}{l}\text { Fetal indication for the abortion licence } \\
\text { request }\end{array}$} & \multicolumn{2}{|c|}{ Licence issued } & \multicolumn{2}{|c|}{ Licence not issued } & \multicolumn{2}{|c|}{ Total } & \multirow[t]{2}{*}{ P-value } \\
\hline & No. & $\%$ & No. & $\%$ & No. & $\%$ & \\
\hline Cardiac anomaly & 18 & 3.0 & 15 & 2.9 & 33 & 3.0 & $0.921^{\mathrm{a}}$ \\
\hline Neurological anomaly & 202 & 33.9 & 87 & 16.9 & 289 & 26.0 & $<0.001^{\mathrm{a}}$ \\
\hline Gastrointestinal anomaly & 16 & 2.7 & 2 & 0.4 & 18 & 1.6 & $0.003^{\mathrm{a}}$ \\
\hline Skeletal deformity & 51 & 8.6 & 28 & 5.4 & 79 & 7.1 & $0.045^{\mathrm{a}}$ \\
\hline Urinary abnormality & 23 & 3.9 & 18 & 3.5 & 41 & 3.7 & $0.753^{\mathrm{a}}$ \\
\hline Blood disorder (not major thalassaemia) & 2 & 0.3 & 0 & 0 & 2 & 0.2 & $0.502^{b}$ \\
\hline Major thalassaemia & 33 & 5.6 & 2 & 0.4 & 35 & 3.2 & $<0.001^{\mathrm{a}}$ \\
\hline Eye anomalies & 0 & 0 & 3 & 0.6 & 3 & 0.3 & $0.099^{\mathrm{b}}$ \\
\hline Genetic disorders & 116 & 19.5 & 46 & 9.0 & 162 & 14.6 & $<0.001^{\mathrm{a}}$ \\
\hline Multisystem involvement & 39 & 6.6 & 13 & 2.5 & 52 & 4.7 & $0.001^{\mathrm{a}}$ \\
\hline Hydrops & 77 & 13.0 & 15 & 2.9 & 92 & 8.3 & $<0.001^{\mathrm{a}}$ \\
\hline Mother on a medication regimen & 0 & 0 & 84 & 16.3 & 84 & 7.6 & $<0.001^{\mathrm{a}}$ \\
\hline $\begin{array}{l}\text { Mother's diagnosed with a disease that could } \\
\text { cause fetal abnormalities }\end{array}$ & 0 & 0 & 20 & 3.9 & 20 & 1.8 & $<0.001^{\mathrm{a}}$ \\
\hline Mother's exposure to radiation & 0 & 0 & 42 & 8.2 & 42 & 3.8 & $<0.001^{\mathrm{a}}$ \\
\hline Ultrasound signs & 1 & 0.2 & 45 & 8.8 & 46 & 4.1 & $<0.001^{\mathrm{a}}$ \\
\hline Positive screening test results for fetal anomalies & 0 & 0 & 24 & 4.7 & 24 & 2.2 & $<0.001^{\mathrm{a}}$ \\
\hline Partial moles & 0 & 0 & 4 & 0.8 & 4 & 0.4 & $0.046^{\mathrm{b}}$ \\
\hline Intrauterine growth restriction & 0 & 0 & 5 & 1.0 & 5 & 0.5 & $0.021^{\mathrm{b}}$ \\
\hline Amniotic fluid disorder & 0 & 0 & 32 & 6.2 & 32 & 2.9 & $<0.001^{\mathrm{a}}$ \\
\hline Intrauterine fetal death & 0 & 0 & 5 & 1.0 & 5 & 0.5 & $0.021^{b}$ \\
\hline Blighted ovum & 0 & 0 & 6 & 1.2 & 6 & 0.5 & $0.010^{\mathrm{b}}$ \\
\hline Conjoined twins & 4 & 0.7 & 1 & 0.2 & 5 & 0.5 & $0.381^{b}$ \\
\hline Other & 14 & 2.3 & 17 & 3.3 & 31 & 2.3 & $0.334^{a}$ \\
\hline Total & 596 & 100 & 514 & 100 & 1110 & 100 & \\
\hline
\end{tabular}

${ }^{a}$ Chi-squared test; ${ }^{b}$ Fisher exact test.

Our results showed that a gestational age over 19 weeks was the most common reason for the not granting an abortion licence (23.4\%). No similar studies were found on this subject.

Our study had some limitations. Because of the high volume of attendees, not all the information on the women and their application was complete. However, this problem was kept to a minimum. Nonetheless, for some women, data were missing for some questions and they were therefore excluded in the percentage calculation for that question. As the sample of women was large, losing such a small number in each question would not likely affect the findings and conclusion.

\section{Conclusion}

Comparison of the results obtained from this study with those from previous studies conducted in the Islamic Republic of Iran showed an increase in the number of women applying for a legal abortion licence and consequently an increase in the number of licences issued. The increase was mostly in applications for fetal rather than maternal indications. The laws introduced on abortion for fetal reasons seem to have led to this increase.

In each country, policies on abortion greatly affect the related implementation. Our findings can help policy-makers to modify existing guidelines for better implementation. For example, the most frequent reason for the non-issuance of a licence was gestational age over 19 weeks because aborting a fetus after 19 weeks is forbidden in the Islamic Republic of Iran. Therefore, early detection of fetal malformations is important and directives should be formulated to encourage and allow for this.

Similar studies are recommended to examine trends over time in the Tehran office and also to examine other offices across the country. Such findings can be used to determine the effect of national abortion laws and to provide information that can help policy-makers to change the abortion laws in the Islamic Republic of Iran based on the existing problems . 


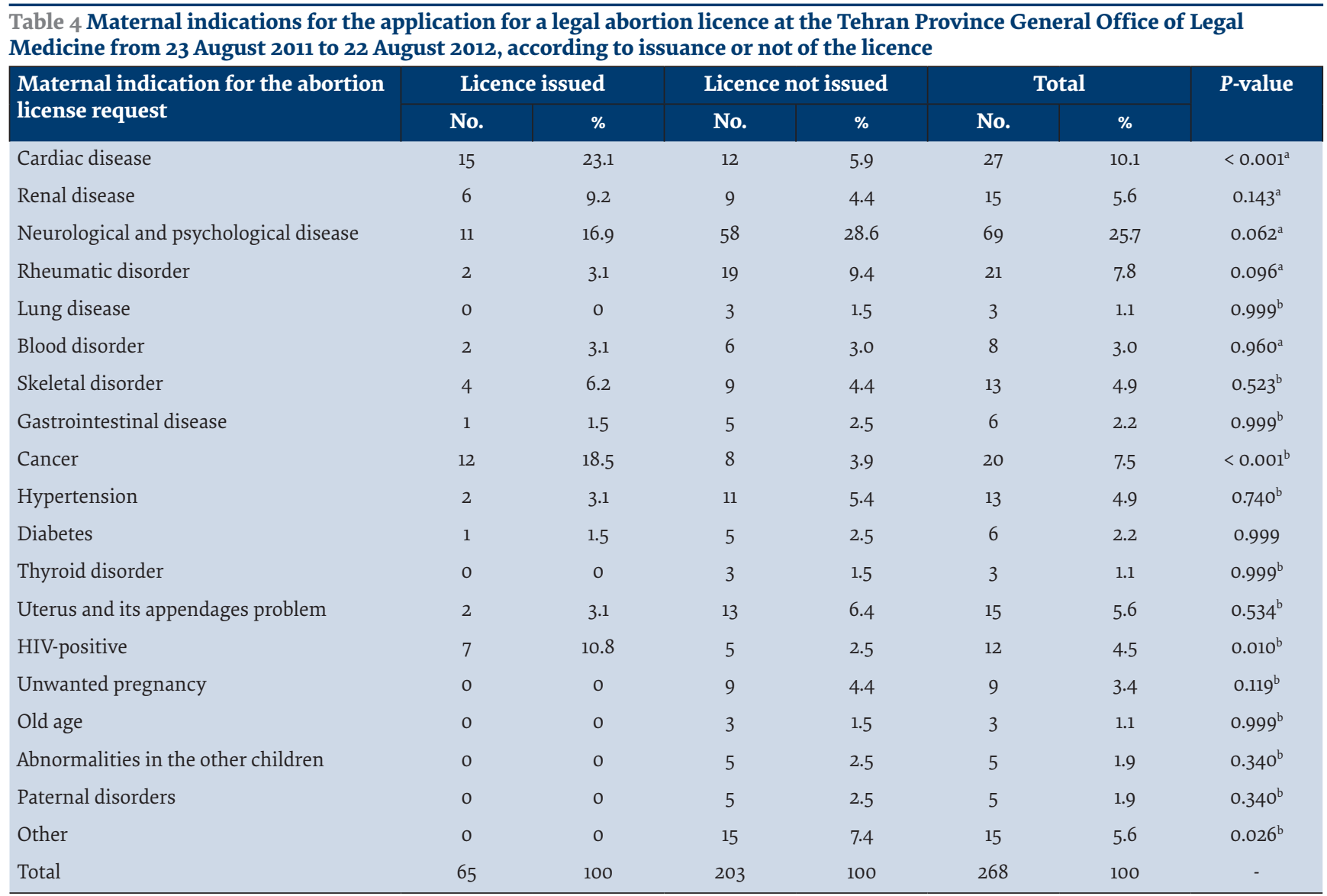

${ }^{a}$ Chi-squared test; ${ }^{b}$ Fisher exact test.

\section{Acknowledgements}

Our special thanks go to all the women whose participation made this research possible. We thank the Tehran University of Medical Sciences for their funding and the Iranian Legal Medicine Organization for their support.

Funding: This study was funded by Tehran University of Medical Sciences.

Competing interests: None declared.

\section{Caractéristiques des femmes présentant une demande d'avortement légal en République islamique d'Iran \\ Résumé}

Contexte : L'avortement légal est autorisé depuis 2003 en République islamique d'Iran dans les cas de maladie grave ou incurable qui causerait une souffrance à la mère ou au fœus.

Objectifs : La présente étude a analysé les caractéristiques des femmes effectuant une demande pour obtenir une autorisation d'avortement légal auprès du Bureau général de médecine légale de la Province de Téhéran, et a procédé à une comparaison des résultats avec des études précédentes de façon à mesurer les changements au fil du temps.

Méthodes: Toutes les femmes se rendant au Bureau entre août 2011 et 2012 pour faire la demande d'une autorisation d'avortement légal ont été interrogées, et les données socio-démographiques, les raisons et l'issue de la demande ont été répertoriées.

Résultats : Au total,1378 femmes ont fait la demande d'une autorisation, et $48 \%$ ont été délivrées. La plupart des demandes (80,6\%) reposaient sur des indications fœetales plutôt que sur des indications maternelles, de même que 90,2\% des autorisations délivrées. La plupart des demandes reposant sur des indications fœtales (53,7\%) se sont vues octroyer une autorisation, tandis que 75,7\% des indications maternelles ont été rejetées. Des anomalies neurologiques chez le fœetus étaient la raison la plus fréquente à l'origine d'une demande $(24,6 \%)$ et des autorisations délivrées (30,7\%). Des troubles neurologiques et psychologiques chez la mère étaient la raison la plus fréquente à l'origine de l'ensemble des 
demandes $(25,7 \%)$ et des refus $(28,6 \%$ ). La présence d'une maladie cardiaque chez la mère $(23,1 \%)$ était la raison la plus fréquente pour une acceptation des demandes.

Conclusions: La comparaison des résultats avec ceux d'études précédentes montre une augmentation du nombre de femmes faisant une demande d'autorisation pour un avortement légal, ainsi qu'une augmentation du nombre des autorisations délivrées. Des études similaires sont recommandées afin de produire des informations sur l'effet des lois nationales relatives à l'avortement, et afin d'accompagner l'amélioration du processus d'avortement légal en République islamique d'Iran.

\section{خصائص السيدات المتقدمات بطلبات الإجهاض القانوني في جمهورية إيران الإسلامية فاطمة واثق رحيم برور، آسية جعفري، فاطمة حسين زادة، فائزه دائمي، فاطمة صمدي}

$$
\begin{aligned}
& \text { الخلفية: تسمح جمهورية إيران الإسلامية بالإجهاض القانوني منذ عام ب...r عندما يهدد مرض خطير وغير قابل للعلاج الأم أو الجنين. }
\end{aligned}
$$

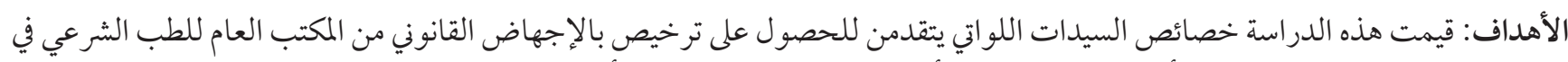

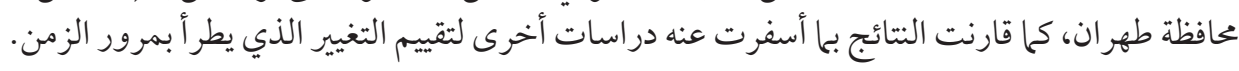

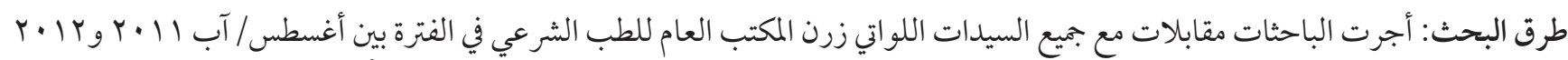

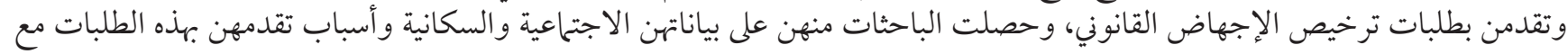
تسجيل نتيجة تلك الطلبات.

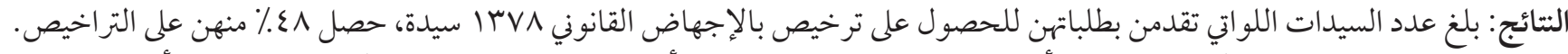

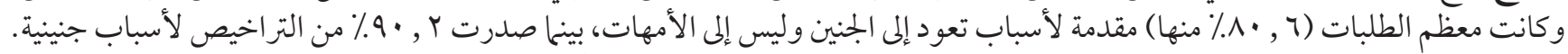

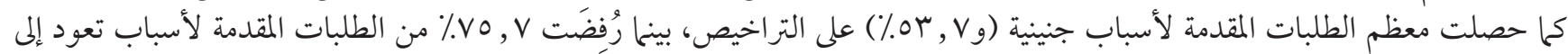

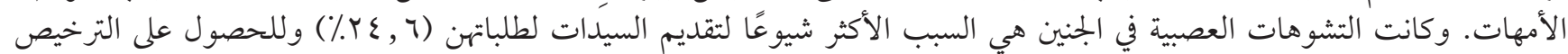

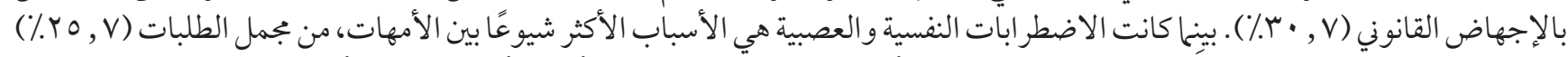

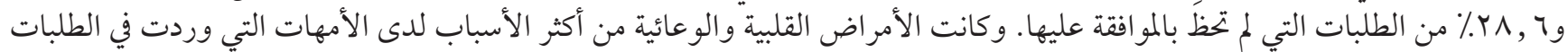

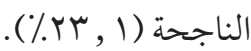

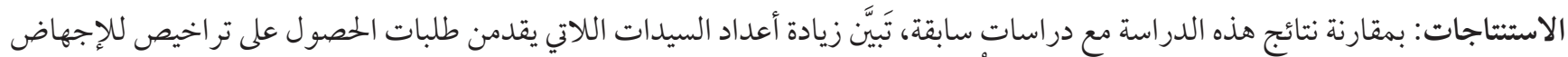

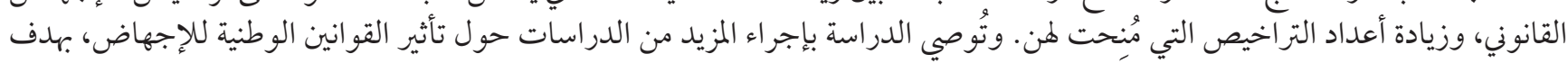

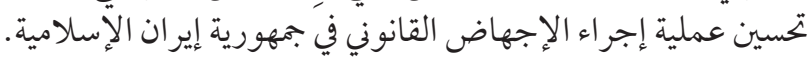

\section{References}

1. Cunningham FG, Williams JW. Williams's obstetrics. New York: McGraw-Hill Medical; 2010.

2. Bazmi Sh, Behnoush B, Kiyani M, Bazmi E. Comparison of legal abortion licenses issued by the Legal Medicine Center in Tehran before the ratification of the legal abortion act in Iran with those after ratification of the act. Iran J Pediatr. 2008;18(4):315-22.

3. Parry J. Screening the genes. Bull World Health Organ. 2012 Aug 1;90(8):564-5. https://doi.org/10.2471/BLT.12.030812 PMID:22893738

4. Shamshiri M. [The health, dimensions of health, and the abortion's stand on the health. Abortion]. Tehran: Research and Development Center for Humanities, Organization for Researching and Composing University Textbooks in the Humanities; 2007. [In Farsi]

5. Behjati Ardekani Z, Akhondi M, Sadeghi MR, Sadri Ardekani H. [The necessity for examining different aspects of abortion. Abortion]. Tehran: Research and Development Center for Humanities, Organization for Researching and Composing University Textbooks in the Humanities; 2007. [In Farsi]

6. Abbasi M, Shamsi Gooshki E, Allahbedashti N. Abortion in Iranian legal system: a review. Iran J Allergy Asthma Immunol. 2014 Feb;13(1):71-84. PMID:24338232

7. Sadr Sh, Aabedi H, Ghadiyani H, Aabedi M. [Determining abortion licenses issued by the State Legal Medicine Organization from December 22nd, 2003 to December 20th, 2004]. Iranian J Forensic Med. 2005;11(4):198-200. [In Farsi]

8. [Abortion is currently one of the threats to women's health]. Tehran: Family Planning Association of the Islamic Republic of Iran; 2007. [In Farsi]

9. [Legal abortion]. Ministry of Health and Medical Education. [webpage] (http://www.behdasht.gov.ir/index.aspx?siteid=1\&pageid=3176, accessed 12 December 2013. [In Farsi] 
10. Keshavarzi F, Khashay M, Alikhani M, Abbasi N. [Examining the causes and complications of the legal abortion in Kermanshah, Iran, in 1996-2001. Abortion]. Tehran: Research and Development Center for Humanities, Organization for Researching and Composing University Textbooks in the Humanities; 2007. [In Farsi]

11. Ehdayivand F, Majidpour A. [The examination of 82 women with septic abortion in Alavi Hospital in Ardebil, Iran, in 1999-2001]. Journal of Medical Council of Iran. 2004;22(1):15-8. [In Farsi]

12. Ghadi Pasha M, Aminiyan Z. [Examining abortion licenses issued by the Legal Medicine General Administration in Kerman Province in 2005 and comparing them with those in previous years]. Journal of Kerman University of Medical Sciences. 2007;14(2):147-52. [In Farsi]

13. Toghifi H, Mousavipour F, Barouni Sh. [Determining the women going to the Medicine Center in Tehran to request for a legal abortion license from May 1999 to May 2000. Abortion]. Tehran: Research and Development Center for Humanities, Organization for Researching and Composing University Textbooks in the Humanities; 2007. [In Farsi] 